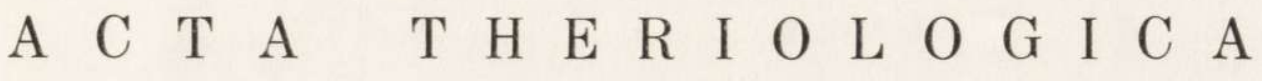

VOL. XVII, 14: 171-186.

BIAŁOWIEŻA

August, 1972

Bogusław B B E K \& Ryszard D Z I E C IO ŁOW S K I

\section{Method of Browse Estimation in Different Types of Forests*}

[With 7 Tables \& 1 Fig.]

In deciduous forests of Carici elongatae-Alnetum type and deciduous forests of Tilio-Carpinetum type the abundance of browse was estimated by the plot-harvest method. The samples of browse were taken in September from 30 fenced subplots $(3 \times 1 \mathrm{~m})$ and from the same number of unfenced ones. The supply of browse on fenced plots reached the following values: young plantation 121.4 , thicket 36.8 and pole-sized stand $19.2 \mathrm{~g}$ dry wt. $/ \mathrm{m}^{2}$. These values on unfenced plots were the following: $57.0,5.2$ and $10.4 \mathrm{~g}$ dry wt. $/ \mathrm{m}^{2}$, respectively. Hence the protection from browsing has a considerable effect on the estimation of food resources for deer. However, due to a high variability of the browse distribution the accuracy of the obtained results was low.

The effect of plot size and number on the estimation of food supply for deer was analysed in deciduous forests of Tilio-Carpinetum type. In November the browse was collected from 30 plots $(3 \times 10 \mathrm{~m})$ divided into subplots $(3 \times 1 \mathrm{~m})$. The most abundant browse supply was found in thickets $\left(44.6 \mathrm{~g}\right.$ dry wt. $\left./ \mathrm{m}^{2}\right)$ and young plantations $\left(11.1 \mathrm{~g}\right.$ dry wt. $\left./ \mathrm{m}^{2}\right)$, and a considerably smaller supply in timber stand $\left(3.3 \mathrm{~g}\right.$ dry wt. $\left./ \mathrm{m}^{2}\right)$ and pole-sized stand $\left(1.8 \mathrm{~g}\right.$ dry wt. $\left./ \mathrm{m}^{2}\right)$. A plot with an area of $21 \mathrm{~m}^{2}$ appeared to be the most useful for investigations. For the proper estimation 5 such plots are required in plantations, 9 in thickets, 14 in timber stands and 18 in pole-sized stand. The unified principles of estimation of the browse supply in the forests of Central Europe have been proposed.

\section{INTRODUCTION}

The elaboration of proper standards of food carrying capacity of a habitat requires an accurate knowledge of its food resources. In case of deer this food supply consists mainly of browse (Si uda, Ż u rowski

* This study was carried out under the Project No. 09.1.7. co-ordinated by the Institute of Ecology Polish Academy of Sciences. 
\& Siuda, 1969; Dzięciołowski, 1970). The browse includes in principle the current growth of trees and shrubs remaining within the reach of animals (De Vos \& M os by, 1969). For this reason an important problem for wildlife economy depends on the quantitative estimation of the abundance of this food supply, especially in winter, when its scarcity occurs. On the other hand, the degree of utilization of food resources is interesting for the Forest Service, because browsing of important plant species causes significant economic losses.

All methods of the browse supply estimation are based on determinations within selected plots, or without them. The browse itself may be clipped (H a lls \& D el1, 1966; D zi ę c i o low ski, 1969), measured by volumetric methods (B u ckman, 1966), or estimated on the basis of the twig numbers (Shafer, 1963; Schruster, 1965). On the other hand, conclusions on the degree of utilization of food resources are usially drawn on the basis of intensity of browsing of individual plant species constituting attractive food for deer (De V os \& M os b y, 1969).

In relation to the 5-year plan of investigations of the game in Poland a necessity arose to elaborate a unified method of estimation of the browse supply. All the methods on this subject that have been described earlier are adapted for the conditions in the habitats in U.S.A., while the elaborations for European forests are lacking. An ideal method of the browse estimation should be not expensive and time consuming, and at the same time it ought to be simple and statistically verifiable. It should also provide quantitative data on the degree of utilization of browse.

\section{AREA OF INVESTIGATIONS, MATERIAL AND METHODS}

The investigations on the browse abundance were carried out in deciduous forests of Tilio-Carpinetum type (Traczyk, 1962; Ferchmin \& Medwecka-Kor$\mathrm{n}$ a ś, 1972) and in alder swamp forests of Carici elongatae-Alnetum type (Koch, 1926) in the variant with Ribes nigrum L. (S ok olow sk i, 1969).

The deciduous forests of Tilio-Carpinetum type (oak-hornbeam forests) grow in the Niepolomice Forest (Forest Inspectorate Damienice, Southern Poland) on fertile soils in the Vistula Valley to the East of Kraków. The most abounding and economically the most important species there is the pedunculate oak, Quercus robur L., which constitutes $60-90 \%$ of species composition. Due to highly favorable habitat conditions these oaks reach usually the Ist or IInd class of site index. In some cases the areas of timber in the age of approximately 150 years are preserved. In respect of number the second place in occupied by the hornbeam, Carpinus betulus L. and small-leaved lime, Tilia cordata Mill. Other species, such as aspen, Populus tremula L. birch, Betula sp. L. and black alder, Alnus glutinosa (L.) Gaertn. constitute a negligible proportion only. The layer of shrubs consists 
mainly of hornbeam undergrowth. A constant admixture is composed of blackberry shrubs, Rubus sp. L., alder buckthorn, Frangula alnus Mill., whitehorn, Crataegus oxyacantha L. and elder, Sambucus nigra I. In these forests cutting down trees is usually carried out in the form of total cuts, approximately $60 \mathrm{~m}$ width. This fact causes that whole parts of stand are in a similar age.

The deciduous forests of Carici elongatae-Alnetum type (alder forests) in the Augustów Forest (Forest Inspectorate Balinka, North-Eastern Poland) are composed of black alder with the admixture of spruce, Picea excelsa (Lam.) Lk., white birch, Betula pubescens Ehrh. and ash, Fraxinus excelsior L.

In the stable communities the layer of shrubs consists mainly of the regeneration of the species forming the timber stand. A constant, though not abundant admixture, is composed of rowan, Sorbus aucuparia L. and shrubs of willow Salix cinercx L. These forests are rather young but fine-looking stands in the age of $40-60$ years. Alders reach the height of 25 to $30 \mathrm{~m}$ d.b.h. of $75 \mathrm{~cm}$.

In May 1971 six plots were selected in alder forests (two in plantations, two in thickets and two in pole-sized stand), $17 \times 17 \mathrm{~m}$ each. Three of them (corresponding to each degree of growth of the forest) were surrounded with the fence of poles $220 \mathrm{~cm}$ high. Then each of these plots was divided into 75 subplots $1 \times 3 \mathrm{~m}$, leaving round the fence an isolatory zone $1 \mathrm{~m}$ broad. The collection of trees, shrubs and dwarf shrubs was carried out in September 1971 on 10 subplots from each plot The subplots were selected by random (drawing of numbers).

In November $19713 \times 10 \mathrm{~m}$ plots were delineated in the deciduous forest of Tilio-Carpinetum type: 5 plots $n$ plantation (2-6 years old) and 5 plots in thickets (815 years old). They were subsequently divided into subplots $3 \times 1 \mathrm{~m}$. In such way 50 subplots were obtained for plantations and 50 for thickets. On the other hand in pole-sized stands ( 30 years old) and timber stand ( 120 year old) 10 plots $3 \times 10 \mathrm{~m}$ were delineated in each type of forest. They were further divided into $3 \times 1 \mathrm{~m}$ subplots yielding in effect 100 subplots each.

The browse was clipped with the pruning shears separately in each subplot. The pruned twigs collected in alder forests or in oak-hornbeam forests were dried at $75^{\circ} \mathrm{C}$ for $48 \mathrm{~h}$ and then weighed to $0.1 \mathrm{~g}$.

\section{RESULTS}

1. The Abundance of Browse in Alder Forest and Oak-hornbeam Forest and its Spatial Pattern

The biomass of current twig growth of trees, shrubs and dwarf-shrubs in three stages of development of alder forest is shown in Table 1. In the plantation the biomass of browse is considerably smaller in an open space than in the fenced plot. Even higher difference is visible in the number of twigs which is reduced by almost three times on the open space. Among 12 species occurring on the fenced plot 10 were found on the open space. The highest differences between fenced and unfenced areas both in respect to biomass and number of twigs, were noted in the thicket. These two values are much higher on fenced plots. Within the fences? 
Table 1

The supply of browse in alder forest.

\begin{tabular}{|c|c|c|c|c|c|}
\hline \multirow[b]{2}{*}{ No. } & \multirow[b]{2}{*}{ Species } & \multicolumn{2}{|c|}{ Fenced plot } & \multicolumn{2}{|c|}{ Open plot } \\
\hline & & $\begin{array}{l}\text { Twig } \\
\text { number }\end{array}$ & $\begin{array}{l}\text { Dry wt. } \\
\mathrm{g} / 30 \mathrm{~m}^{2}\end{array}$ & $\begin{array}{l}\text { Twig } \\
\text { number }\end{array}$ & $\begin{array}{l}\text { Dry wt. } \\
\mathrm{g} / 30 \mathrm{~m}^{2}\end{array}$ \\
\hline \multicolumn{6}{|c|}{ Young plantation } \\
\hline 1. & Fraxinus excelsior L. & 30 & 1908.1 & 49 & 1141.8 \\
\hline 2. & Alnus glutinosa (L.) Gaertn. & 248 & 806.8 & 78 & 183.6 \\
\hline & Rubus ideus L. & 209 & 280.7 & 19 & 31.7 \\
\hline 4. & Solanum dulcamara L. & 87 & 188.4 & 29 & 95.8 \\
\hline & Tilia cordata Mill. & 107 & 188.3 & 68 & 123.3 \\
\hline 6. & Betula pubescens Ehrh. & 190 & 144.5 & 38 & 70.8 \\
\hline 7. & Unidentified dwari-shrub & 20 & 80.3 & - & $\overline{01}$ \\
\hline 8. & Sorbus aucuparia L. & 7 & 22.3 & 18 & 21.3 \\
\hline 8. & Salix spp. & 8 & 16.9 & 3 & 5.4 \\
\hline 10. & Ribes nigrum L. & 5 & 2.8 & 8 & 9.3 \\
\hline 11. & Populus tremula L. & 1 & 2.6 & - & $\overline{906}$ \\
\hline 12. & Corylus avellana L. & 1 & 0.3 & 4 & \\
\hline & Total & 913 & 3642.0 & 314 & 1711.6 \\
\hline \multicolumn{6}{|c|}{ Thicket } \\
\hline 1. & Corylus avellana $\mathrm{L}$. & 772 & 320.5 & 34 & \\
\hline 2. & Rubus ideus L. & 331 & 297.4 & 19 & $\begin{array}{l}14.4 \\
35.3\end{array}$ \\
\hline 3. & Fraxinus excelsior L. & 230 & 257.9 & 68 & 35.3 \\
\hline & Picea excelsa (Lam) Lk. & 1144 & 142.4 & - & $\overline{-}$ \\
\hline 5. & Frangula alnus Mill. & 70 & 32.9 & 45 & 19.4 \\
\hline 6. & Salix spp. & 27 & 15.1 & 9 & 7.6 \\
\hline 7. & Betula pubescens Ehrh. & 40 & 11.5 & - & $\overline{30}$ \\
\hline & Alnus glutinosa (L.) Gaertn. & 30 & 8.6 & 14 & $\begin{array}{r}3.8 \\
40.3\end{array}$ \\
\hline & Sorbus aucuparia L. & 13 & 5.1 & 12 & 40.3 \\
\hline 10. & Salix caprea L. & 1 & 4.9 & - & - \\
\hline 11. & Viburnum opulus L. & 9 & 4.2 & 120 & 22.4 \\
\hline 12. & Vaccinium myrtillus L. & 30 & 1.6 & - & - \\
\hline 13. & Quercus robur L. & 3 & 0.5 & - & $\overline{34}$ \\
\hline 14. & Ribes nigrum L. & - & 一 & 6 & \\
\hline & Total & 2700 & 1102.6 & 327 & 154.6 \\
\hline \multicolumn{6}{|c|}{ Pole-sized stand } \\
\hline 1. & Fraxinus excelsior L. & 297 & 282.7 & 174 & 165.8 \\
\hline 2. & Corylus avellana L. & 382 & 92.1 & - & - \\
\hline 3. & Padus avium Mill. & 291 & 74.7 & - & - \\
\hline 4. & Tilia cordata Mill. & 300 & 51.8 & - & - \\
\hline 5. & Picea excelsa (Lam.) Lk & 1017 & 48.7 & - & - \\
\hline 6. & Evonymus europea L. & 115 & 10.0 & $\overline{6}$ & \\
\hline 7. & Acer platanoides L. & 8 & 9.1 & 6 & 1.7 \\
\hline 8. & Populus tremula L. & 2 & 4.3 & $\overline{3}$ & $\overline{0.5}$ \\
\hline 9. & Sorbus aucuparia L. & 7 & $\begin{array}{l}1.8 \\
0.1\end{array}$ & 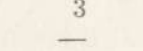 & - \\
\hline & $\begin{array}{l}\text { Betula pubescens Ehrh. } \\
\text { Frangula alnus Mill. }\end{array}$ & 1 & - & 340 & 94.5 \\
\hline $\begin{array}{l}11 . \\
12 .\end{array}$ & $\begin{array}{l}\text { Frangula alnus Mill. } \\
\text { Rubus idaeus L. }\end{array}$ & - & - & 28 & 20.5 \\
\hline & Ribes nigrum L. & - & - & 22 & 17.4 \\
\hline \multirow[t]{2}{*}{14.} & Alnus glutinosa (L.) Gaertn & - & - & 9 & 10.1 \\
\hline & Total & 2420 & 575.3 & 582 & 311.5 \\
\hline
\end{tabular}


area there occurred 5 plant species which were lacking on the open space; on the other hand the black currant was found only on the open space (Table 1).

In the case of pole-sized stand the difference between the fenced and unfenced plot is the smallest. A considerable variability in the species composition of the two plots is striking. From among 10 species occurring on the fenced area only 3 were found on the open space, where other 4 different species, absent on the fenced plot, were observed. Large differences in the number of sprouts, occurring in thickets and pole-sized

Table 2

\begin{tabular}{|c|c|c|}
\hline Stage of forest growth & Fenced area & Open area \\
\hline $\begin{array}{l}\text { Young plantation } \\
\text { Thicket } \\
\text { Pole-sized stand }\end{array}$ & $\begin{array}{r}121.4 \\
36.8 \\
19.2\end{array}$ & $\begin{array}{r}57.0 \\
5.2 \\
10.4\end{array}$ \\
\hline Mean & 58.0 & 24.2 \\
\hline
\end{tabular}

Table 3

Comparison of plant species showing the highest difference in the biomass of browse between fenced and open plots jointly in all stages of regeneration of the stand.

\begin{tabular}{lc} 
Plant species & $\begin{array}{c}\text { Difference in the browse biomass } \\
\text { between fenced and open plots } \\
\text { (in g dry wt.) }\end{array}$ \\
\hline Fraxinus excelsior L. & 1104.8 \\
Alnus glutinosa (L.) Gaertn. & 617.9 \\
Rubus idaeus L. & 511.5 \\
Corylus avellana L. & 376.3 \\
Picea excelsa (Lam.) Lk. & 191.1 \\
Tilia cordata Mill. & 116.8 \\
\hline
\end{tabular}

stands in favour of fenced plots are caused in part by the spruce which was present within fenced areas.

It is characteristic that in all stages of the development of forest association the subplots on the open space show considerably smaller biomass of twigs in comparison with fenced areas. This difference is the highest (almost 6-fold) in the case of thicket (Table 2).

In table 3 six plant species are listed which show the highest difference in the biomass of browse between fenced and unfenced areas in 
favour of the former. Assuming that a significant part of these differences was caused by browsing mooses and deer on unfenced plots (as indicated by numerous remnants of browsed twigs) this list indicates the most preferred and most abundant plant species constituting the browse.

A detailed analysis of the browse supply and its spatial arrangemen: in oak-hornbeam forests on open plots is depicted in Tables 4 and 5 . Moreover, the food abundance for particular plots and subplots is given, and the mean values for the subplots of analogous number are computed.

Table 4

Estimation of the browse supply $\left(\mathrm{g}\right.$ dry $\left.\mathrm{wt} . / \mathrm{m}^{2}\right)$ in the plantations and thickets of the oak-hornbeam forest. The data give the browse supply in individual subplot: $(1 \times 3 \mathrm{~m})$ and their mean values $\left(\bar{x}_{a}\right)$ calculated for 5 subplots of the same numbering. The mean $\left(\bar{x}_{b}\right)$ were computed from the cumulative series $\left(\Sigma \bar{x}_{a}\right)$ on the basis of an increasing number of subplots (from 5 to 50). A - number of subplots $(1 \times 3 \mathrm{~m})$.

\begin{tabular}{|c|c|c|c|c|c|c|c|c|}
\hline \multirow[b]{2}{*}{ A } & \multicolumn{5}{|c|}{ Plot number $(3 \times 10 \mathrm{~m})$} & \multirow[b]{2}{*}{$\bar{x}_{a}$} & \multirow[b]{2}{*}{$\sum \bar{x}_{a}$} & \multirow[b]{2}{*}{$\bar{x}_{b}$} \\
\hline & I & II & III & IV & V & & & \\
\hline \multicolumn{9}{|c|}{ Young plantation } \\
\hline 1. & 10.1 & 18.6 & 8.8 & 9.4 & 9.1 & 11.2 & 11.2 & 11.2 \\
\hline 2. & 18.1 & 22.4 & 15.1 & 16.0 & 14.2 & 17.2 & 28.4 & 14.2 \\
\hline 3. & 12.9 & 12.6 & 33.2 & 23.1 & 12.1 & 18.8 & 47.2 & 15.7 \\
\hline 4. & 14.9 & 10.1 & 12.3 & 13.3 & 13.0 & 12.7 & 59.9 & 15.0 \\
\hline 5. & 8.5 & 22.1 & 2.8 & 5.7 & 4.0 & 8.6 & 68.5 & 13.7 \\
\hline 6. & 8.1 & 8.9 & 4.8 & 2.8 & 1.7 & 5.2 & 73.7 & 12.3 \\
\hline 7. & 7.9 & 5.1 & 9.1 & 8.1 & 9.5 & 7.9 & 81.6 & 11.6 \\
\hline 8. & 13.9 & 0.7 & 6.1 & 11.7 & 10.8 & 8.6 & 90.2 & 11.3 \\
\hline 9. & 14.5 & 16.7 & 16.3 & 16.4 & 13.3 & 15.4 & 105.6 & 11.7 \\
\hline 10. & 8.1 & 9.0 & 4.6 & 3.0 & 1.5 & 5.2 & 110.8 & 11.1 \\
\hline \multicolumn{9}{|c|}{ Thicket } \\
\hline 1. & 20.7 & 74.4 & 65.1 & 29.0 & 32.6 & 44.4 & 44.4 & 44.4 \\
\hline 2. & 25.9 & 89.6 & 78.4 & 49.8 & 54.1 & 59.5 & 103.9 & 51.9 \\
\hline 3. & 30.3 & 51.6 & 44.1 & 109.5 & 80.8 & 63.3 & 167.2 & 55.7 \\
\hline 4. & 28.9 & 59.6 & 35.3 & 40.5 & 46.5 & 42.2 & 209.4 & 52.4 \\
\hline 5. & 46.4 & 88.4 & 77.3 & 19.2 & 20.0 & 50.2 & 259.6 & 51.9 \\
\hline 6. & 40.1 & 32.8 & 31.1 & 15.5 & 25.0 & 23.9 & 288.5 & 48.1 \\
\hline 7. & 70.6 & 39.5 & 17.8 & 30.0 & 28.3 & 37.2 & 325.7 & 46.5 \\
\hline 8. & 35.1 & 55.6 & 20.0 & 20.1 & 40.9 & 34.3 & 360.0 & 45.0 \\
\hline 9. & 32.7 & 58.0 & 58.4 & 53.8 & 57.4 & 52.1 & 412.1 & 45.8 \\
\hline 10. & 35.2 & 32.4 & 31.5 & 20.1 & 50.0 & 33.8 & 445.9 & 44.6 \\
\hline
\end{tabular}

These mean values were then cumulated and the obtained results represent the data from the successively increasing area. This gives a basis for the calculation of the browse supply in the plots (cumulated subplots) of various size: from 3 to $30 \mathrm{~m}^{2}$.

When the estimate of the browse supply in the largest plots $\left(30 \mathrm{~m}^{2}\right)$ - $\quad$ is assumed as the criterion, then it appears that this supply is highly dif- 
ferentiated and depends on the forest age. The thicket was found to be the richest in this respect and the second place is occupied by the plantation (Table 4). The pole-sized stand shows a sligtly lower food supply than the timber stand, but the two last stages of forest development differ drastically from the two former stages (Table 5).

In a thicket $1 \mathrm{~m}^{2}$ gives as much as $44.6 \mathrm{~g}$ dry wt. of browse, and not a single plot lacking this food was found. The maximum amount in the thicket was equal to $109.5 \mathrm{~g}$ dry $\mathrm{wt} . / \mathrm{m}^{2}$, the minimum $-15.5 \mathrm{~g}$. The standard deviation was found to be $\pm 21.7 \mathrm{~g}$ dry wt. $/ \mathrm{m}^{2}$, and the coeffi-

Table 5

Estimation of the browse supply (g dry wt. $/ \mathrm{m}^{2}$ ) in the pole-sized stand and timbe: stand. The data give the browse supply in individual subplots $(1 \times 3 \mathrm{~m})$ and their mean values $\left(\bar{x}_{a}\right)$ calculated from 10 subplots of the same numbering. The means $\left(\bar{x}_{b}\right)$ were computed from the cumulative series $\left(\Sigma \bar{x}_{a}\right)$ of the basis of an increasing number of subplots (from 10 to 100$)$. A - number of subplots $(1 \times 3 \mathrm{~m}$ ).

\begin{tabular}{|c|c|c|c|c|c|c|c|c|c|c|c|c|c|}
\hline \multirow[b]{2}{*}{ A } & \multicolumn{10}{|c|}{ Plot number $(3 \times 10 \mathrm{~m})$} & \multirow[b]{2}{*}{$\bar{x}_{a}$} & \multirow[b]{2}{*}{$\sum \bar{x}_{a}$} & \multirow[b]{2}{*}{$\bar{x}_{b}$} \\
\hline & I & II & III & IV & $\mathrm{V}$ & VI & VII & VIII & IX & $\mathrm{x}$ & & & \\
\hline \multicolumn{14}{|c|}{ Pole-sized stand } \\
\hline 1. & 1.2 & 2.5 & 0.1 & 2.1 & - & 0.5 & 0.4 & 2.2 & 0.5 & 1.7 & 1.1 & 1.1 & 1.1 \\
\hline 2. & - & 0.7 & 0.2 & 3.6 & 0.4 & 0.5 & 0.6 & 0.3 & 3. & & & 2. & 1.1 \\
\hline 3. & 0.3 & 4.6 & - & 1.4 & 0.8 & 1.7 & 1.3 & 0.1 & 2.2 & 1 & & 3.7 & 1.2 \\
\hline 4. & 0.1 & 5.9 & 0.4 & - & 0.9 & 3.1 & 0.5 & 2.6 & 0.1 & 3 & & 5.5 & 1.4 \\
\hline 5. & 1.3 & 7.3 & 0.9 & 1.3 & 3.5 & 0.6 & 2.0 & 1.7 & 1.1 & 0. & 2. & 7.5 & 1.5 \\
\hline 6. & 1.7 & 3.0 & 0.7 & 1.4 & 1.8 & 1.2 & 1.3 & 4.5 & 6. & 0. & 2. & 9.7 & 1.6 \\
\hline 7. & 1.7 & 0.7 & 2.6 & 6.2 & 12.4 & 3.5 & 0.6 & 4.5 & 2.2 & 0. & 3. & 13.2 & 1.9 \\
\hline 8. & 1.2 & 1.3 & 0.7 & 0.1 & 2.8 & 5.0 & 1.0 & 2.5 & 0.4 & 1 & 1. & 14.8 & 1.8 \\
\hline 9. & 2.4 & 0.6 & 3.7 & 0.4 & 6.8 & 1.0 & 0.5 & 0.8 & 2.5 & 2.8 & 2.1 & 16.9 & 1.9 \\
\hline 10. & 2.8 & 一 & 1.1 & 0.4 & - & 0.2 & 1.1 & 0.8 & 0.2 & 1.3 & 1.1 & 18.0 & 1.8 \\
\hline \multicolumn{14}{|c|}{ Timber stand } \\
\hline 1. & 1.0 & 0.7 & 4.7 & 4.3 & 1.0 & 1.3 & 3.3 & 7.7 & - & 1.0 & 2. & 2.5 & 2.5 \\
\hline 2. & 1.0 & 1.3 & 0.7 & 2.0 & 7.0 & 5. & 3.3 & 2.7 & 1.0 & & & & 25 \\
\hline 3. & 3.3 & 2.7 & 0.3 & 0.7 & 4.3 & 1.7 & 3.7 & 4.3 & - & 2. & 2. & 7.3 & 2.4 \\
\hline 4. & 6.3 & 1.0 & 5.3 & 5.0 & 1.7 & 2.3 & 6.6 & 1.7 & - & 4. & 3. & 10.7 & 2.7 \\
\hline 5. & 1.7 & 4.3 & 3.3 & 2.3 & 1.7 & 1.0 & 1.3 & 1.3 & - & 1. & 1. & 12.5 & 2.5 \\
\hline 6. & 2.7 & 2.7 & 9.0 & 3.7 & 13.0 & 2.0 & 1.3 & 0.3 & 3.7 & 3. & 4. & 16.7 & 2.8 \\
\hline 7. & 1.3 & 7.7 & 9.3 & 2.3 & 4.3 & 2.3 & 1.0 & 3.0 & - & 8. & 4. & 20.7 & 3.0 \\
\hline 8. & 2.0 & 10.3 & 5.0 & 0.7 & 0.7 & 4.7 & 2.0 & 3.7 & 4.0 & 2. & 3. & 24.3 & 3.0 \\
\hline 9. & 10.3 & 2.0 & 1.7 & 9.0 & 5.0 & 2 . & 5.3 & 1.0 & 12.7 & 0. & 5. & 29.2 & 3.2 \\
\hline 10. & 2.0 & - & 1.7 & 6.0 & - & 2.7 & 2.7 & 4.0 & 8.0 & 5.0 & 3.2 & 32.5 & 3.2 \\
\hline
\end{tabular}

cient of variability - $48.6 \%$. When the supply of browse is estimated from plots of different size it may be concluded that the increase of the plot area above $18 \mathrm{~m}^{2}$ does not give any change in estimation. The mosit probable and accurate determination obtained from $30 \mathrm{~m}^{2}$ plots is very similar to the estimates from the plots of $18,21,24$ or $27 \mathrm{~m}^{2}$. The discrepancies do not exceed $10 \%$ (Table 4 ). 
Plantations of the oak-hornbeam forest occupy the second place (after thicket) in respect of food supply. It was estimated that $1 \mathrm{~m}^{2}$ provides there $11.1 \mathrm{~g}$ dry wt. of browse, and standard deviation calculated for 50 subplots amount to 6.30 dry $\mathrm{wt} . / \mathrm{m}^{2}$. This gives the coefficient of variability amounting to $57.0 \%$, which is similar to that in thickets. Similarly, no plots devoid of browse were noted, but the range of maximum and minimum values is higher: from 0.7 to $33.2 \mathrm{~g}$ dry $w t . / \mathrm{m}^{2}$ (Table 4 ). The effect of plot size on the estimation of browse supply resembles that found in thickets. Starting from the plots of $18 \mathrm{~m}^{2}$ the estimates do not differ from the values obtained for $30 \mathrm{~m}^{2}$ plots by more than $10 \%$ (Table 4).

The supply of browse in the pole-sized stand and timber stand is very irregular. The differences between particular subplots are drastic and some subplots are entirely devoid of browse. On the other hand in some subplots the supply of browse reaches $12.4 \mathrm{~g}$ dry wt. $/ \mathrm{m}^{2}$ (pole-sized stand), and 13.0 dry wt. $/ \mathrm{m}^{2}$ (timber stand) (Table 5). For this reason the estimations of browse supply in both these stages of the forest development are more difficult and should be based on larger plots. In the pole-sized stand only the plots of $21 \mathrm{~m}^{2}$ (or larger) give the estimates similar to the mean based on $30 \mathrm{~m}^{2}$ plots. Both classes of the forest show very low food supply. In the pole-sized stand only $1.8 \mathrm{~g}$ dry wt. of browse fells for $1 \mathrm{~m}^{2}$, and the distribution is uneven. For this reason standard deviation reaches here 1.9 dry wt. $/ \mathrm{m}^{2}$ and $C . V .=109.6 \%$ (highest for all stages of the forest development). A comparably low amount of browse - only $3.2 \mathrm{~g}$ dry wt. per $1 \mathrm{~m}^{2}$ - was found in the timber stand. Its spatial pattern is also uneven: the browse was lacking on 7 subplots, standard deviation amounted to $2.9 \mathrm{~g}$ dry wt. $/ \mathrm{m}^{2}$, and C.V. $=90.6 \%$.

bed be the following expression:

\section{The Accuracy of Biomass Estimation}

The accuracy in the estimation of the mean biomass of twigs is descri bed by the following expression:

$$
d=\frac{t \alpha \cdot S \bar{x}}{\bar{x}} \cdot 100 \%
$$

where $d-$ accuracy of estimation, $t-$ value from the tables of $t$-Student test at $n-1$ degrees of freedom and confidence level $(1-\alpha)=0.95$, $S_{\bar{x}}$ - mean error of the arithmetic mean, which can be expressed by the following formula:

$$
S_{x}=\sqrt{\frac{\left(\overline{\left.x_{i}-\bar{x}\right)^{2}}\right.}{n(n-1)}}
$$

where $x_{i}$ - single determination of biomass, $\bar{x}$ arithmetical mean of $n$ determinations, $n$ - humber of determinations. 
The calculations, carried out according to formula (1), of the estima tion accuracy of the browse biomass in three stages of development of alder forest gave the results shown in Table 6. It appears that the accuracy of the results obtained is relatively low since the values obtained are high. This is caused by a considerable variability of biomass in individual subplots. The variability results from aggregated distribution of sprouts of deciduous species. A closer analysis of dispersion (spatial pattern) of the browse in oak-hornbeam forests demonstrated that also there the browse is distributed in aggregations. When the dispersion is estimated as the ratio of the standard deviation in the second power (determined for individual subplots) to the arithmetical mean, then the follo-

Table 6

\begin{tabular}{|c|c|c|c|c|}
\hline Stage of forest growth & $\mathrm{n}$ & $\bar{x}$ & $S_{x}$ & $d$ \\
\hline Fenced young plantation & 10 & 121.4 & 63.16 & 117.7 \\
\hline Open young plantation & 10 & 57.1 & 44.83 & 177.7 \\
\hline Fenced thicket & 10 & 36.8 & 9.44 & 58.0 \\
\hline Open thicket & 10 & 5.1 & 2.40 & 105.4 \\
\hline Fenced pole-sized stand & 10 & 18.9 & 4.18 & 50.1 \\
\hline \multirow[t]{2}{*}{ Open pole-sized stand } & 10 & 10.4 & 2.26 & 49.2 \\
\hline & 60 & 41.6 & 31.92 & 153.5 \\
\hline
\end{tabular}

wing values are obtained: the pole-sized stand 2.0 , timber stand -2.6 , plantation -3.6 and thicket - 21.7. Hence these values exceed considerably the mean and increase with its rise, which is typical for aggregated distributions (L e w is \& T a y lor, 1968).

\section{Estimation of the Representative Number of Plots}

In all investigations on food resources one of the most important elements depends on the accuracy of estimation of the obtained results. To obtain accurate results we must know the plot size and number of determinations for each stage of the forest development. The confidence interval, at which the results are compared, as well as the assumed accuracy of the arithmetic mean, are also important in this respect.

Large differences between fenced and unfenced plots indicate that the estimation of food supply should be based on fenced plots, otherwise the results may be greatly underestimated. This is suggested both by the 
data from the first part of Results and by the quantitative informations on browsing of roe and red deer (Bobek, Weiner \& Zieliński. 1972). The establishment of the plot size and number is also an important factor. As demonstrated above, the accuracy of estimation of the biomass in alder forest is very low on account of clustered distribution of the browse. For this reason in order to estimate properly the browse in alder forest the samples should be taken from as many as 588 subplots ( $3 \mathrm{~m}^{2}$ each) - a procedure certainly unprofitable in respect of time required.

Table 7

Estimation of representative area of the plants and their number in the investigations of the browse supply in plantations, thickets, pole-sized stand and timber stand in the oak-hornbeam forest. The data below have been estimated at 9 degrees of freedom and 0.05 confidence level; the accuracy of the mean $-20 \%, \bar{x}-$ browse supply ( $\mathrm{g}$ dry $\mathrm{wt} . / \mathrm{m}^{2}$ ), SD - standard deviation, CV - coefficient of variability, $\mathrm{N}$ - required number of plots.

\begin{tabular}{|c|c|c|c|c|c|c|c|c|c|c|}
\hline \multicolumn{11}{|c|}{ Size of plot $\left(\mathrm{m}^{2}\right)$} \\
\hline & 3 & 6 & 9 & 12 & 15 & 18 & 21 & 24 & 27 & 30 \\
\hline \multicolumn{11}{|c|}{ Young plantation } \\
\hline $\begin{array}{l}\bar{x} \\
\pm \mathrm{SD}\end{array}$ & $\begin{array}{r}11.2 \\
4.2\end{array}$ & 14.2 & 15.7 & 15.0 & 13.7 & 12.3 & 11.6 & 11.3 & 11.7 & 11.1 \\
\hline $\begin{array}{l} \pm \mathrm{SD} \\
\mathrm{CV}\end{array}$ & $\begin{array}{r}4.2 \\
\end{array}$ & 3.7 & 3.7 & 2.0 & 2.4 & 2.0 & 1.8 & 1.2 & 1.2 & 1.4 \\
\hline $\mathrm{N}$ & $\begin{array}{l}37.5 \\
27.6\end{array}$ & $\begin{array}{l}26.1 \\
13.3\end{array}$ & 23.6 & 13.3 & 17.5 & 16.3 & 15.5 & 10.6 & 10.2 & $12 .{ }^{5}$ \\
\hline & & & & 3.0 & 6.0 & 5.2 & 4.7 & 2.2 & 2.1 & 3.1 \\
\hline $\bar{x}$ & \multicolumn{10}{|c|}{ Thicket } \\
\hline$\pm \mathrm{SD}$ & $\begin{array}{l}44.3 \\
23.8\end{array}$ & 52.0 & 55.7 & 52.4 & 51.9 & 48.1 & 46.5 & 45.0 & 45.8 & 44.5 \\
\hline $\mathrm{CV}$ & $\begin{array}{l}20.0 \\
53.7\end{array}$ & $\begin{array}{l}24.0 \\
46.1\end{array}$ & 17.8 & 15.7 & 15.7 & 13.0 & $\begin{array}{r}9.9 \\
91.9\end{array}$ & 9.8 & 8.1 & 8.4 \\
\hline $\mathrm{N}$ & 56.6 & $\begin{array}{l}46.1 \\
41.7\end{array}$ & $\begin{array}{l}31.9 \\
20.2\end{array}$ & $\begin{array}{l}29.9 \\
17.5\end{array}$ & $\begin{array}{l}30.2 \\
17.9\end{array}$ & $\begin{array}{l}27.0 \\
14.3\end{array}$ & $\begin{array}{r}21.3 \\
8.9\end{array}$ & $\begin{array}{r}21.8 \\
9.3\end{array}$ & $\begin{array}{r}17.7 \\
6.1\end{array}$ & $\begin{array}{r}18.3 \\
7.0\end{array}$ \\
\hline \multicolumn{11}{|c|}{ Pole-sized stand } \\
\hline $\bar{x}$ & 1.1 & 1.1 & 1.2 & 1.4 & 1.5 & 1.6 & 1.9 & 1.8 & 1.9 & 1.8 \\
\hline \pm SD & 0.9 & 0.9 & 0.9 & 1.0 & 1.1 & 1.0 & 0.7 & 0.7 & 0.7 & 0.6 \\
\hline CV & 81.8 & 81.8 & 75.0 & 71.4 & 73.3 & 62.5 & 36.8 & 38.9 & 36.8 & 33.3 \\
\hline $\mathrm{N}$ & 85.5 & 85.5 & 71.8 & 65.2 & 68.7 & 49.9 & 17.6 & 19.2 & 17.6 & 14.1 \\
\hline \multicolumn{11}{|c|}{ Timber stand } \\
\hline $\bar{x}$ & 2.5 & 2.5 & 2.4 & 2.7 & 2.5 & 2.8 & 3.0 & 3.0 & 3.2 & 3.2 \\
\hline$\pm \mathrm{SD}$ & 2.4 & 1.6 & 1.4 & 1.2 & 1.0 & 1.1 & 1.0 & 1.0 & 0.7 & 0.5 \\
\hline $\mathrm{CV}$ & 96.0 & 64.0 & 58.3 & 44.4 & 40.0 & 39.2 & 33.3 & 33.3 & 21.9 & 15.6 \\
\hline $\mathrm{N}$ & 117.6 & 52.4 & 43.5 & 25.2 & 20.4 & 19.7 & 14.2 & 14.2 & 6.1 & 3.1 \\
\hline
\end{tabular}

The accurate analysis in order to estimate the representative number of plots of a given area was carried out in oak-hornbeam forests on the basis of Tables 4 and 5. At first there were determined the means and standard deviations for the plots of increasing area - from 3 to $30 \mathrm{~m}^{2}$, and then the data were substituted into the formula:

$$
n=\frac{S^{2} \cdot t^{2}}{d^{2}}
$$


where: $n$ - number of required plots, $S$ - standard deviation, $t-$ degrees of freedom at 0.05 confidence level, $d-$ mean $\times$ planned accuracy. All these calculations are summarized in Table 7 ; the estimations were made at 0.05 confidence level and $20 \%$ accuracy of the mean.

From the calculations carried out according to this principle it appears that the pole-sized stand is the stage of forest development in which the estimation of food supply is the most difficult. When estimating the food

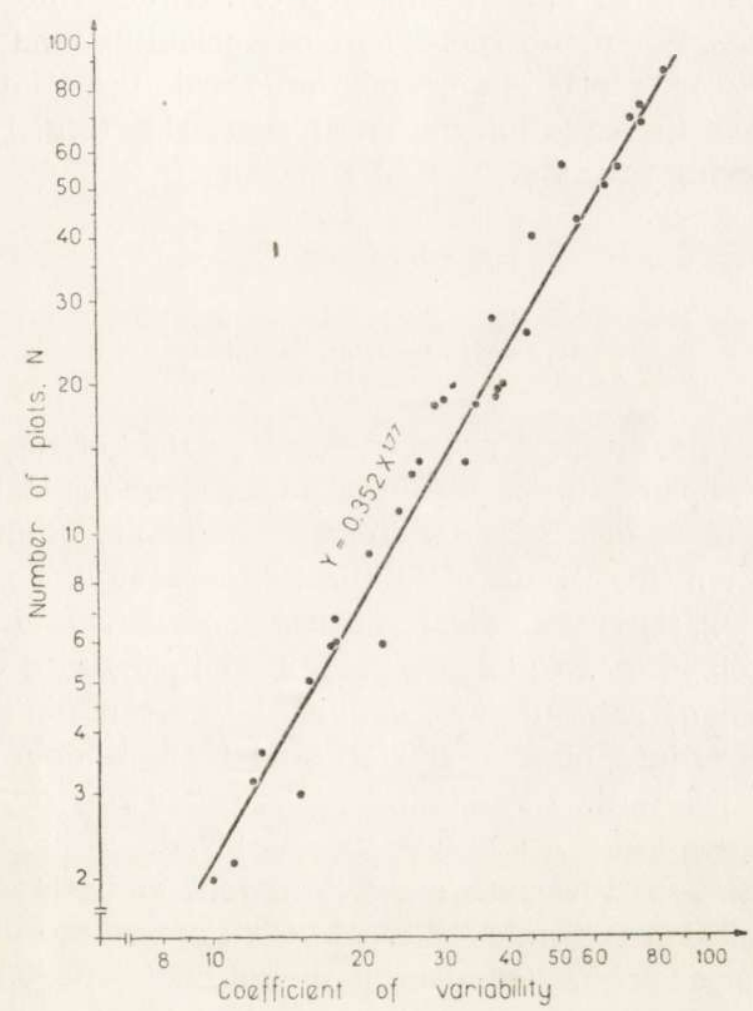

Fig. 1. The effect of coefficient of variability on the number of plots in the studies of food resources of deciduous forests.

supply on $3 \mathrm{~m}^{2}$ plots as many as 85 plots should be used; the estimation of biomass on $30 \mathrm{~m}^{2}$ plots requires 14 plots. The timber stand is slightly better for such estimations: although 117 plots $3 \mathrm{~m}^{2}$ each required for the proper estimation but this number promptly decreases with larger plots (Table 7).

Plantations and thickets were found to be the most suited for any estimation of browse supply. Only 28 and 57 plots $3 \mathrm{~m}^{2}$ each are required 
for plantations and thickets, respectively, and with $30 \mathrm{~m}^{2}$ these values are reduced to 3 and 7 plots only (Table 7 ).

It seems that in oak-hornbeam forests $21 \mathrm{~m}^{2}$ plots are most recommended. At this plot area 5 plots should be delineated in plantations, 9 plots in thickets. Considerably higher numbers are required for the pole-sized stand (18) and for timber stand (14 plots).

It should be concluded that the number of plots required for obtaining representative results depends mainly on the coefficient of variability, and is proportional to it. This relationship can be described by an equation of the curve. When the coefficient of variability and the required number of plots were plotted in a logarithmic scale the relationship could be calculated from the equation for linear regression (Fig. 1) and expressed by the following formula: $\mathrm{Y}=0.352 \mathrm{X}+1.77$

\section{DISCUSSION}

\section{Localization of Samples}

Sampling plots should be situated in typical stands of the studied environment. Both types of the area (fenced and open) should be present iv: the same stand to secure better uniformity of plant composition.

There are known three ways of localization of sampling plots (De V o s \& M o s b y, 1969): (1) systematical and mechanical (e.g. along a definite course of the compass the plots are arranged in definite distances), (2) random selection of azimuth and distances between plots, (3) division of the whole area into numbered plots and then random drawing plot numbers. The third method seems to be best suited for the investigations in which both open and fenced plots are employed.

In many studies on the state of environment of herbivorous animals the climax vegetation is employed as a model, according to which actual plant associations are classified, even if they do not represent the climax. The investigations on the browse supply in forest communities (D e 11 a-Bianca \& Johnson, 1965; Stransky \& Halls, 1967; Young, Hedrick \& Keniston, 1967; Dzięciołowski, 1970; Halls, 1970) demonstrated, however, significant differences in the biomass of browse in relation to the stage of succession (regeneration) of the association. It was found that younger stages of succession (plantations and occasionally thickets) are characterized by a considerably higher biomass of browse than intermediate stages (pole-sized stands). The biomass of twigs increases later in parallel to loosening the canopy in mature timber stand. Hence it is essential to take into consideration this time-dependent variability in the localization of sampling plots. The experimental 
system should include the stratification of samples in relation to ident1fied stages of succession of forest association. In the investigations presented here three stages of succession of alder forest after clearing have been distinquished: plantation (2-6 years after cutting the timber), thicket (7-15 years) and pole-sized stand (III and IV age class of the stand). In other forest association (e.g. oak-hornbeam forests) moreover the stage of timber stand should be distinguished; it includes both the trees mature for cutting and those over-mature.

\section{Estimation of the Number, Shape and Size of Plots}

In the studies on the biomass of browse the plots of differrent size and shape have been used. The last studies (De V os \& M o s b y, 1969) demonstrated that the shape of the sampling plot is more important than previously suspected. For low plants (below $1 \mathrm{~m}$ high) circular plot has clear advantages. The circle may be quickly and accurately delineated in the terrain. Rectangle plots are usually more effective than square plots of uniform size. Short strips give less variable results than squares but are still more variable than long strips. In the investigations described here the plots $1 \times 3 \mathrm{~m}$, and their multiples, were employed.

When the type of plant cover is uniform and hence suitable for the random sampling a decision on the assumed accuracy is required even before the number of samples is established. Also the knowledge of the confidence level, margin of the error and standard deviation are essential. The size (i.e. numbers) of samples cannot be established without knowing standard deviation $(S)$. This value is best estimated on the basis of preliminary samples taken in open areas, as it was made in oak-hornbeam forests.

On account of considerable variability in the distribution of browse biomass it is impossible to give a general formula for the size and number of plots. In order to assure the comparability of results it is suggested to assume $20 \%$ accuracy of the mean at 0.05 confidence level.

\section{Fencing}

It was demonstrated (Sh a f er, 1965) that the smaller area the lower fencing is required; e.g. the area of 1 miliacre should be surrounded by the fence of $1.2 \mathrm{~m}$ high. Larger areas need $3 \mathrm{~m}$ high fence. Fencing of large areas ( 0.5 ha or more) involve proportionally high costs of maintenance. H e a d y (1968) concluded that the minimum size of any fencing remaining in one place for over 1 year should amount to 0.1 ha. Smaller 
areas are subjected to excessive effects of the border. The most open-work construction is recommended for fencing in order to reduce the effect of fence on wind, light, temperature and drifted snow.

\section{Technique and Periods of Collection}

The twigs of this year growth are clipped from all dwarf-shrubs, shrubs and trees on the plot from the level of ground (or snow) up to $1.5 \mathrm{~m}$ (if the browsing by roe deer is studied), to $2.0 \mathrm{~m}$ (red deer) or $2.5 \mathrm{~m}$ (moose). The twigs are cut with pruning shears and transferred to plastic bags separately for each species. Two periods of collection are suggested: after comletion of growth of the twig length and full development of leaves (September), and after winter browsing but before opening buds (March). During the first collection the biomass of stems and leaves should be estimated separately. Due to this procedure the estimation of biomass in spring can be limited to open plots only.

\section{Counting of Browsed Twigs}

Before pruning twigs on the open plots all freshly browsed stems should be counted, taking into account different plant species. Moreover, the diameter of the browsed twig should be determined with a slide calliper at the point of browsing.

\section{Determination of Dry Weight}

In the investigations carried out hitherto the air-dried biomass weight of twigs was determined by drying at $95^{\circ} \mathrm{C}$ for 24 hours ( $\mathrm{Y}$ o u n g, H e ndrick \& Kenisto n, 1967). It is better, however, to establish the dry weight after 48 hours drying at $75^{\circ} \mathrm{C}$.

\section{REFERENCES}

1. Bobek B., Weiner J. \& Zieliński J., 1972: Food supply and their consumption by deer in a deciduous forest of Southern Poland. Acta theriol., 17. $187-202$.

1. Buckman R. E., 1966: Estimation of cubic volume of shrubs (Corylus spp.). Ecology, 47, 4: 858-860.

3. Della-Bianca L. \& Johnson F. M., 1965: Effect of an intensive cleaning on deer-browse production in southern Appalachians. J. Wildl. Mgmt., 29, 4: $727-733$.

4. De Vos A. \& Mos by H. S., 1969: Habitat analysis and evaluation. [In: "Wild life management techniques«, Ed. R. H., Giles] The Wildlife Society: 135-172. Washington D. C. 
5. Dzięciolowski R., 1969: Winter biomass of browse for herbivorous animals in forest habitats. Ekol. pol. A, 17, 20: 361-372.

6. Dzięciolowski R., 1970a: Foods of the red deer as determined by rumen content analyses., Acta theriol., 15, 6: 89-110.

7. D z i ęc i ołowski R., 1970b: Biomasa roślin runa leśnego oraz podszytów jako potencjalna baza pokarmowa zwierząt roślinożernych. Folia Forestalia Polonica, A, 16: 69-90.

8. Ferchmin M. \& M edwecka-Kornaś A., 1972: Lasy dębowe (Tilio-Carpinetum) w północnej części Puszczy Niepołomickiej. Studia Naturae, 8.

9. Halls L. K. \& Dell T. R., 1966: Trial of ranked-set sampling for forage yields. For. Sci., 12: 22-26.

10. H a $11 \mathrm{~s} \mathrm{~L}$. K., 1970: Growing deer food amidst southern timber. J. Range Mgmt., 23, 3: $213-215$.

11. Lewis T. \& T a y lor L. R., 1968: Introduction to experimental ecology. Academic Press. 1-401. London - New York.

12. Schruster J. L., 1965: Estimating from twig and stem measurements. J. Range Mgmt., 18, 4: 220-222.

13. Sh af er E. L. Jr., 1963: The twig-count method for measuring hardwood deer browse. J. Wild. Mgmt., 27: 428-437.

14. Shafer E. L. Jr., 1965: Deer browsing of hardwoods in the Northeast. U.S. Forest Service Research Paper NE-33.

15. Siuda A., Żurowski W. \& Siuda H., 1969: The food of the roe deer. Acta theriol., 14, 18: 247-262.

16. Sok ołowski A. W., 1969: Zespoły roślinne nadleśnictwa Balinka w Puszczy Augustowskiej. Monographiae Botanicae, 28: 1-79.

17. Stransky J. J. \& Halls L. K., 1967: Timber and game relations in pine-hardwood forests of the southern United States. XIV IUFRO-Kongress, München 1967, Papers VII, Section 26: 208-217.

18. Young J. A., Hedrick D. W. \& Keniston R. F., 1967: Forest cover and logging-herbage and browse production in the mixed coniferous forest of northeastern Oregon. J. Forestry, 65, 11: 807-813.

Accepted, March 17, 1972.

Departament of Animal Genetics and Organic Evolution,

Jagiellonian University,

Kraków 2, Krupnicza 50, Poland.
Departament of Game Management, and Forestry Research Institute,

Warszawa,

Wery Kostrzewy 3 , Poland.

Bogusław BOBEK i Ryszard DZIĘCIOEOWSKI

\section{OCENA ŻERU PĘDOWEGO W RÓŻNYCH TYPACH LASU}

Streszczenie

W olsach Carici elongatae Alnetum na terenie Puszczy Augustowskiej (Nadl. Balinka) i grądach Puszczy Niepołomickiej (Nadl. Damienice) oceniono zasobność żeru 
pedowego. Na terenie olsów w maju 1971 wytyczono 6 działek - po dwie w każdym stadium rozwojowym lasu jak uprawa, młodnik i drągowina. Wszystkie działki podzielono na poddziałki, $3 \times 1 \mathrm{~m}$ a następnie trzy działki ogrodzono płotem żerdziowym jako zabezpieczenie przed żerowaniem jeleniowatych. We wrześniu przeprowadzono zbiór pędów drzew, krzewów i krzewinek na 60 poddziałkach, z których 30 bylo ogrodzonych.

We wszystkich stadiach rozwojowych drzewostanu biomasa żeru pędowego była niższa na działkach nieogrodzonych (Tabela 1). Wartości te wynosiły odpowiednio $121,4 \mathrm{~g}$ (uprawa), 36,8 (młodnik) i $19,2 \mathrm{~g}$ suchej masy/m² (drągowina) dla działek grodzonych, a tylko $57,0,5,2$ i 10,4 g suchej masy/m² na dzialkach nieogrodzonych (Tabela 2). Największe różnice w biomasie żeru pędowego zarejestrowano u jesiona, olchy i świerka (Tabela 3).

Badania zasobności pokarmowej w grądach przeprowadzono na 30 działkach otwartych podzielonych na poddziałki $(3 \times 1 \mathrm{~m})$, które rozlokowano w uprawie (5), młodniku (5), drągowinie (10) oraz starodrzewiu (10). Zbiór żeru pędowego przeprowadzono w listopadzie ścinając go odrębnie na poszczególnych poddziałkach. Jeśli jako kryterium przyjmiemy ocenę zasobności uzyskaną z działek o powierzchni $30 \mathrm{~m}^{2}$. to najbogatsze $\mathrm{w}$ żer pędowy okazały się młodniki ( $44,6 \mathrm{~g}$ suchej masy $/ \mathrm{m}^{2}$ ), a następnie uprawy (11,1 g) (Tabela 4). Dużo mniej żeru pędowego bo tylko $3,2 \mathrm{~g}$ i $1,8 \mathrm{~g}$ suchej masy $/ \mathrm{m}^{2}$ uzyskano $\mathrm{w}$ starodrzewiu i drągowinie (Tabela 5). Na podstawie wzoru (3) ustalono, że najbardziej przydatną do badań jest działka o powierzchni $21 \mathrm{~m}^{2}$.

Do prawidłowej oceny ( 0.05 poziom ufności i $20 \%$ dokładność średniej) wymagane jest 5 takich działek w uprawach, $9 \mathrm{w}$ młodnikach, $14 \mathrm{w}$ starodrzewiu i $18 \mathrm{w}$ drągowinie (Tabela 7). Dokładność szacowania dla działek mniejszych jest bardzo niska co powoduje skupiskowość rozmieszczenia żeru pędowego i wysoki współczynnik zmienności (Fig. 1, Tabela 6).

$\mathrm{Na}$ podstawie powyższych wyników zaproponowano następującą metodę oceny żeru pędowego:

1. Wszelkie oceny zasobności żeru pędowego w lasach należy wykonać metodą żniwną na działkach grodzonych i nieogrodzonych.

2. Działki należy rozmieścić w czterech stadiach rozwojowych lasu jak: uprawa (2-6 lat), młodnik (7-15 lat), drągowina (40-60 lat) i starodrzew w wieku 90 i więcej lat.

3. Ze względu na dużą zmienność zapasu żeru pędowego niemożliwe jest podanie jednolitego przepisu na wielkość i ilość działek. Dlatego też przed przystąpieniem do badań należy dla każdego stadium rozwojowego drzewostanu oszacować odchylenie standartowe i na podstawie wzoru (3) ustalić wielkość i ilość działek. Przy ustalaniu tych wartości proponuje się przyjąć 0,05 poziom ufności i $20 \%$ dokładność średniej.

4. Żer pędowy należy przycinać na wysokości $1,5 \mathrm{~m}$ jeżeli badamy bazę pokarmasową sarny, 2,0 m jeżeli chodzi o żerowanie jeleni i 2,5 m dla łosi. Proponuje się przyjęcie dwóch terminów zbioru: po skończonym przyroście i pełnym rozwoju liści, oraz po okresie zimowego zgryzania.

5. Na działkach otwartych przed każdym przystąpieniem do zbioru należy policzyć ilość pẹdów zgryzionych, a suwmiarką zmierzyć średnicę zgryzów.

6. Wszelkie wyniki podawać w suchej masie. 